methylated allele, however, was detected only in tumours that also showed a methylated allele by Southern blot hybridisation.

To show that the RBI-MSP is applicable in routine DNA samples with unknown methylation status was tested by the RB1-MSP. All tumours had been investigated for $\mathrm{LOH}$ at $\mathrm{RBi2}$ and RB1.20. In two of these samples, a methylated $R B 1$ promoter region was identified by the MSP assay and verified by Southern blot analysis. Although this is a small number of tumours, the finding of methylated $R B 1$ alleles in $10 \%$ of unilateral sporadic retinoblastomas is in agreement with previous estimates on the frequency of hypermethylated $R B 1$ alleles." An additional $154 \mathrm{bp}$ PCR product representing an unmethylated allele was also obtained in these two tumours, which was to be expected as they did not show LOH at the intragenic polymorphic loci $\mathrm{RBi} 2$ and $\mathrm{RB} 1.20$.

In summary, analysis of 40 samples has shown that our MSP reliably identifies tumours with hypermethylated $R B 1$ alleles as detected by Southern hybridisation. Compared to Southern blot analysis, however, MSP is faster, can be performed with small amounts of genomic DNA, and does not need radioactive components. Thus, MSP facilitates identification of $R B 1$ gene hypermethylation in RB and other tumours. ${ }^{12}$

Part of this work was supported by the Deutsche Krebshilfe. We thank Martina Klutz and Christina Lich for technical assistance. diagnosis, a second set of 20 randomly selected tumour

MICHAEL ZESCHNIGK

DIETMLAR LOHMIANN BERNHARD HORSTHEMKE

Institut für Humangenetik, Hufelandstrasse 55, D-45122 Essen, Germany

1 Lohmann DR, Gerick M, Brandt B, et al. Constitutional RBI-gene mutations in patients with isolated unilateral retinoblastoma. $A m \mathrm{~J} \mathrm{Hum}$ Genet 1997;61:282-94.

2 Ohtani-Fujita N, Fujita T, Aoike A, Osifchin NE, Robbins PD, Sakai T. CpG methylation inactivates the promoter activity of the human retinoblastomar tumor-suppressor gene. Oncogene 1993;8:1063-7.

3 Greger V, Passarge E, Höpping W, Messmer E, Horsthemke B. Epigenetic Greger V, Passarge E, Hopping changes may contribute to the formation

4 Greger V, Debus N, Lohmann D, Höpping W, Passarge E, Horsthemke B. Frequency and parental origin of hypermethylated RB1 alleles in retinoblastoma. Hum Genet 1994;94:491-6.

5 Herman JG, Graff JR, Myohänen S, Nelkin BD, Baylin SB. A novel PCR assay for methylation status of CpG islands. Proc Natl Acad Sci USA 1996; 93:9821-6.

6 Dobrovic A, Simpfendorfer D. Methylation of the BRCAl gene in sporadic breast cancer. Cancer Res 1997;16:3347-50.

7 Sakai T, Toguchida J, Ohtani N, Yandell DW, Rapaport JM, Dryja TP. Allele-specific hypermethylation of the retinoblastoma tumor-suppressor gene. Am f Hum Genct 1991; $48: 880-8$

8 Stirzaker C, Millar DS, Paul CL, $t$ t al. Extensive DNA methylation spanning the $\mathrm{Rb}$ promoter in retinoblastoma tumors. Cancer Res 1997;57: 2229-37.

9 Zeschnigk M, Lich C, Buiting K, Doerfler W, Horsthemke B. A single-rube PCR test for the diagnosis of Angelman and Prader-Willi syndrome based on allelic methylation differences at the SNRPN locus. Eur $f$ Hum Gente on allelic meth

10 TAng A, Wu KJ, Hashimoto $T$, et al. Genomic organization of the human retinoblastoma gene. Oncogene 1989;4:404-7.

11 Clark SJ, Harrison J, Paul CL, Frommer M. High sensitivity mapping of methylated cytosines. Nucleic Acids Res 1994;22:2990-7.

12 Horowitz JM, Park SH, Bogenmann E, et al. Frequent inactivation of the retinoblastoma anti-oncogene is restricted to a subset of human tumor cells. Proc Nat Acad Sci USA 1990;87:2775-9.

F Med Genet 1999;36:794-795

\section{Frequency and predictive value of 22q11 deletion}

EDITOR-Malformations resulting from the adverse effects of $22 \mathrm{q} 11$ deletion are now recognised to be of one of the most important diagnostic categories in dysmorphology. The predictive value of this common deletion remains to be fully elucidated since even large reviews ${ }^{1}$ are by their nature subject to ascertainment bias. In our original report of familial heart disease associated with submicroscopic 22 q11 deletion, which predated the routine availability of fluorescence in situ hybridisation (FISH), the carrier mother was dysmorphic but had a normal heart. ${ }^{2}$ We and others have drawn attention to the marked variability of the phenotype and the need to be alert to the possibility of subtle features in a parent..$^{3-5}$ These observations raise the possibility of subclinical deletion being more common than has been recognised. This would have significance in genetic counselling when $22 \mathrm{q} 11$ deletion is detected in the first trimester as occurred in the case described below.

Following the recognition of a deletion $22 \mathrm{q} 11$ in III.2 (fig 1) diagnosed clinically as DiGeorge syndrome with complex cardiac malformations including pulmonary atresia, double outlets of the right ventricle, subaortic interventricular septal defect, mitral atresia, restrictive intra-atrial communication, hypoplastic left ventricle, patent ductus arteriosus, and right aortic arch leading to neonatal death, the parents were invited to undergo chromosome analysis. The father (II.4) (fig 2) was found to carry a del22q11.1-11.2 karyotype and displayed minor facial features, mild learning difficulties, and was on the 10 th centile for height. ${ }^{*}$ The couple went on to have three subsequent pregnancies. In their third pregnancy, early amniocentesis showed a $22 \mathrm{q} 11$ deletion but no evidence of

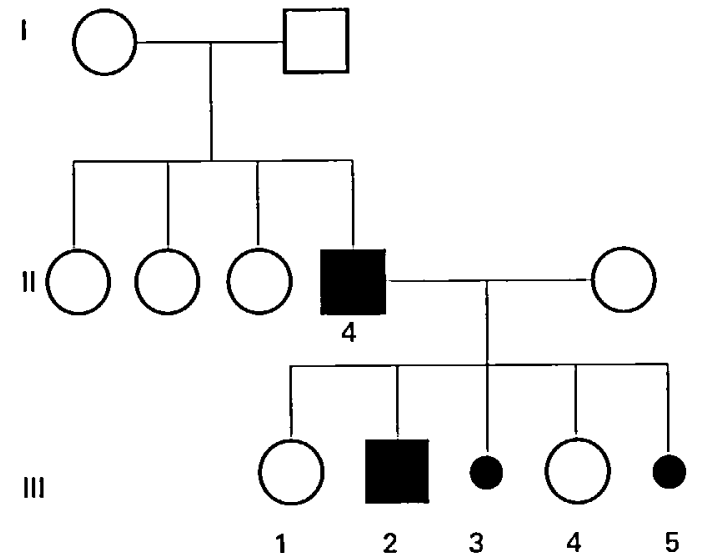

Figure $122 q 11$ deletion in tzo generations with marked variation in phenotype.

structural abnormality was detected on an anomaly scan and fetal echocardiography at the 17th and 18th week. A further examination at 19 weeks showed a major structural heart defect. At necropsy the aborted fetus (III.3) was found to have slightly abnormal facial features, pulmonary atresia, perimembraneous ventricular septal defect, secunartery, a small thymus, and one ectopic parathyroid. The couple's fourth pregnancy resulted in a healthy daughter (III.4) while their fifth (III.5) was a severely affected fetus with $22 \mathrm{q} 11$ deletion who died in utero.

There have been eight reports of prenatal diagnosis based on a $22 \mathrm{q} 11$ deletion but the growing recognition of this disorder in clinical practice means this will become a more common event. In order to improve the predictive value of detection of $22 \mathrm{q} 11$ deletion in pregnancy, we undertook an investigation of $22 \mathrm{q} 11$ deletion in an unselected population. dum atrial septal defect, retro-oesophageal right subclavian 


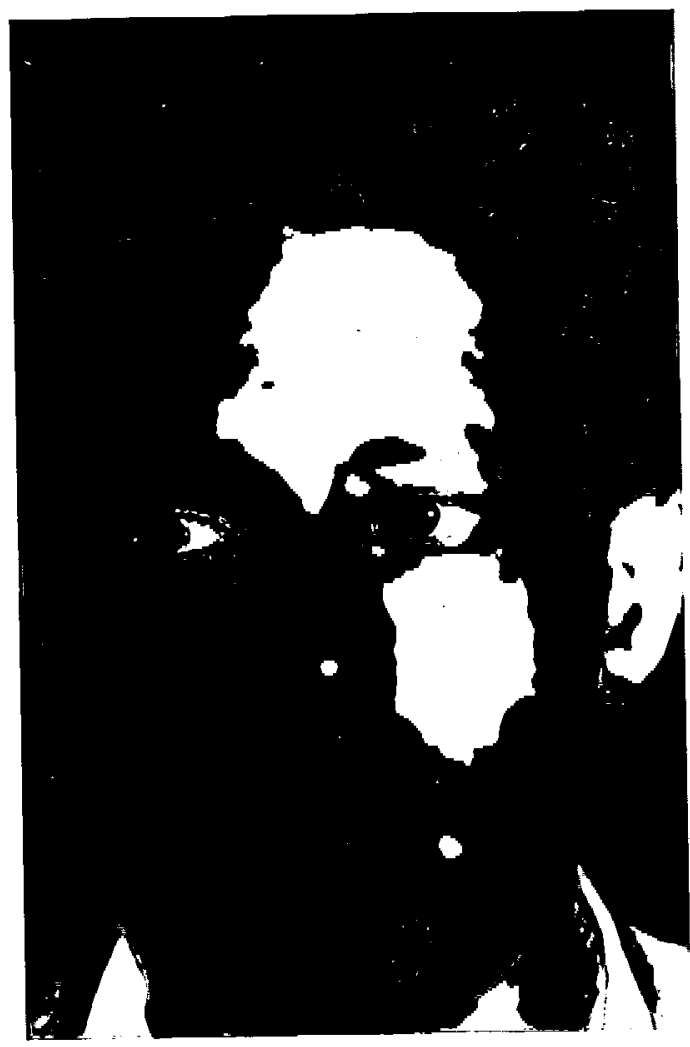

Figure 2 The father found to have $22 q 11$ deletion had minimal clinical features (reproduced from Burn et al, 1995, with permission).

The North Cumbria Community Genetics Project (NCCGP) was established in 1996 to provide a consecutive series of samples from all newborn infants in a defined area. With the written consent of parents, samples of cord blood, viable cells, tissue, and DNA are collected and stored. ${ }^{\circ}$ NCCGP samples were analysed by dual colour FISH using cosmid probes specific to the commonly deleted area. Probe F5429 contains sequences from the TUPLE-1 region, ${ }^{7}$ and probe F9130 encompasses the ADU/VDU breakpoint isolated from an apparently balanced $t(2 ; 22)$ translocation identified from both a severely affected daughter with DiGeorge syndrome and her mildly affected mother. ${ }^{8}$ Both probes detect sequences from the proximal shortest region of overlap (SRO) of 22 q11 deletions and, according to Rauch et al, ${ }^{9}$ could detect approximately $90 \%$ of all potential deletions in the chromosome region of $22 q 11$. Three specimens known to carry a 22q1 1 deletion mixed with the NCCGP samples on a blind basis were all detected correctly, but no $22 \mathrm{q} 11$ deletions were detected among 1731 study samples.

Based on a Poisson distribution, the highest prevalence of 22q11 deletion at birth with which these data are compatible is 1 in 577 ( $p>0.95)$ and we conclude, therefore, that the frequency of this deletion in the general population is probably less than 1 in 600 . Jacobs $e t$ al $l^{10}$ estimated the frequency of all unbalanced chromosome abnormalities to be 1 in 1639. This estimate predated the availability of routine FISH analysis for $22 \mathrm{q} 11$ and other microdeletions. Previous estimates of the prevalence of this deletion have relied on results from cases with clinical abnormalities, and minimum values of about 1 in 4000,111 in $6000,{ }^{12}$ and 1 in $10000^{13}$ have been reported. A study in the Northern Region of England of $22 \mathrm{q} 11$ deletion associated with significant malformations estimated its prevalence at around 1 in 10000 births. ${ }^{14}$ This was based on referrals with medical complications early in life, particularly to the paediatric cardiology service. Since cases with less obvious congenital defects continue to present later in childhood, ${ }^{14}$ it is apparent that the previous reports represent minimum estimates of the prevalence in the whole population. By comparing our unselected population data with the middle estimate for minimum prevalence ( 1 in 6000 ) we conclude that when $22 \mathrm{q} 11$ deletion is discovered in pregnancy, the chance of major malformation is at least $10 \%$ and further investigation such as high resolution ultrasound scan and fetal echocardiography are indicated.

JESSE L.ILING IAN CROSS JOHN BURN

Department of Human Genetics, University of Newcastle upon Tyne, Nezcastle upon Tyne NE2 4AA, UK

C PAUL DANIEL E JANET TAWN

Genetics Unit, Westlakes Research Institute, Moor Row, Cumbria CA24 2JY, UK

LOUISE PARKER Institute of Child Health, Royal Victoria Infirmary, Newcastle upon Tyne NEl $4 L P$, UK

1 Ryan AK, Goodship JA, Wilson DI, et al. Spectrum of clinical features asso(a) 22q1 deletions: a European ciated with interstitial chromosome 22ql1 del

2 Wilson DI, Cross IE, Goodship JA, et al. DiGcorge syndrome with isolated aortic coarctation and isolated ventricular septal defect in three sibs with a 22 11 deletion of maternal origin. Br Heart $\mathcal{F} 1991 ; 66: 308-12$.

3 Lipson A, Emanuel B, Colley P, Fagan K, Driscoll DA. “CATCH 22" sans cardiac anomaly, thymic hypoplasia, cleft palate, and hypocalcaemia: $c$ Atch 22. A common result of 22q11 deficiency? J Med Genet 1994;31:741.

4 Burn J, Wilson DI, Cross I, et al. The clinical significance of $22 \mathrm{q} 11.2$ deleBurn J, Wilson DI, Cross I, et al. Tr, Takao A, eds. Developmental mechanisms tion. In: Clark EB, Markwald RR, Takao A, eds. Dretopmental

of heart disease. Armonk, NY: Futura Publishing, IS, Wulfsberg EA. Familial Leana-Cox J, Pangkanon S, Eanet KR, Curtin MS, Kuls chromosome area DiGeorge/relocardiofacial syndrome with deletions of chromosome area 22q11.2: report of five

Genet 1996;65:309-16. 6 Chase DS, Tawn EJ, Parker I, Jonss P, Parker CO, Burn J. The Nort

Cumbria Community Genetics Project. F Mled Genet 1998;35:413-16.
Halford S, Wadey R, Roberts C, et al. Isolation of a putative transcriptional regulator from the region of 22q11 deleted in DiGeorge syndrome, Shprintzen syndrome and familial congenital heart disease. Hum Mol Genet 1993;12:2099-107.

8 Budarf $\mathrm{MIL}$, Collins J, Gong W, et al. Cloning a balanced translocation associated with DiGeorge syndrome and identification of a disrupted candidate gene. Nat Genet 1995;10:269-78.

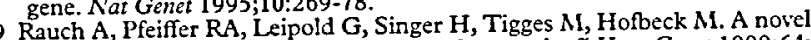
22q11.2 microdeletion in DiGeorge syndrome. Am $\mathcal{J ~ H u m ~ G e n e t ~ 1 9 9 9 ; 6 4 ~}$ 22q11.2

10 Jacobs PA, Browne C, Gregson N, Joyce C, White H. Estimates of the frequency of chromete newborns quency of chromosome abnormalities detectable in unselected

11 Wing DI, Cross IE, Wren C. A Minimum prevalence of chromosome 22q11 deletions. Am J Hum Genet 1994;55:A169.

12 Tezenas Du Montcel S, Mendizabai H, Ayme S, Levy A, Philip N. Prevalence of 22q11 microdeletion. J A Ted Genet 1996;33:719.

13 Devriendt K, Fryns JP, Mortier G, van Thienen MiN, Keymolen $\mathrm{K}$. The annual incidence of DiGeorge/velocardiofacial syndrome. I Med Gener 1998;35:789-90.

14 Goodship J, Cross I, LiLing J, Wren C. A population study of chromosome 22q11 deletions in infancy. Arch Dis Child 1998;79:348-51. 